\title{
POLICY OF SPECIAL ECONOMIC ZONES AND ENVIRONMENTAL POLICIES IN BANGKA BELITUNG: A STAKEHOLDER ANALYSIS
} Kismartini $^{1^{*}}$, Ali Roziqin ${ }^{2}$, Hartuti Purnaweni ${ }^{3}$, Bulan Prabawani ${ }^{4}$, Muhammad Kamil ${ }^{5}$

${ }^{1 *}, 3$ Department of Public Administration, Universitas Diponegoro, Semarang, Indonesia; ${ }^{2,5}$ Department of Government Science, Universitas Muhammadiyah Malang, Indonesia; ${ }^{4}$ Department of Business Administration, Universitas Diponegoro, Indonesia.

Email: "kismartini@live.undip.ac.id

\author{
Article History: Received on $19^{\text {th }}$ June 2020, Revised on $20^{\text {th }}$ August 2020, Published on $1^{\text {st }}$ October 2020
}

\begin{abstract}
Purpose of the Study: The purpose of this article was to categorize and identify the role of stakeholders in the development of SEZs policy. Furthermore, the researchers set limits on the development of SEZs policy in Tanjung Gunung and Sungailiat.

Methodology: This article used qualitative research with approach Participatory Action Research (PAR). The data were obtained through in-depth interviews, observation, and a literature study about the focus of research. The researchers also conducted focus group discussions with related agencies or institutions within the Bangka Belitung Province Government, Bangka Regency, and Central Bangka Regency.

Main Findings: The results indicate that many stakeholders are involved in the SEZs policy from within both the central government and local governments. In addition, there are additional key stakeholders namely central government as represented by National Council. The primary stakeholders are local governments, and the secondary stakeholders are the mining entrepreneurs and the wider community.
\end{abstract}

Application of this study: The importance of stakeholder analysis is to resolve any that arise in the development of SEZ policies in Bangka Belitung. Moreover, stakeholder analysis can help to limit the issues that can be solved in ways that are technically applicable and politically appropriate by prioritizing the common interests and greater good.

Novelty/Originality: No specific research discussing the SEZ policy in Bangka Belitung, especially stakeholder analysis, has been conducted before. Stakeholder analysis identifies policy actors to realize the development of SEZs policy in Bangka Belitung which environmental friendly.

Keywords: Special Economic Zones, Stakeholder Analysis, Environmental Policy, Power, Interest.

\section{INTRODUCTION}

Tin mining and Bangka Belitung are two entities that cannot be separated from each other (Darwance et al, 2017). Tin mining in Bangka Belitung has been around for a long time and even before the era of colonialism (Ibrahim, 2016). For a long time, tin production from Bangka Belitung has become one of the largest producers in Southeast Asia (Erman, 2010; Ibrahim, 2016; Sujitno, 2007). According to several geolofical surveys in 2015, tin ore reserves in Indonesiaespecially Bangka Belitung- are the second largest in the world (Friana, 2018). This means that Bangka Belitung has abundant natural resources.

In the post-reform era, there has been a change in the government system in Indonesia. During both the old and new orders, the control of the tin mines was very strong and secures (Erman, 2008). This had an impact on the governance of the tin mining in Bangka Belitung. Mining governance is only controlled by the State through several National Companies (BUMN). This monopolistic nature causes social heartburn in the community, so starting in 2000 , unconventional people-focused mining has emerged. As the results indicate, the level of tin mining activity Bangka Belitung has increased significantly.

Unconventional mines have been developing continuously and the number is increasing every year. Unconventional mining is growing out of control, starting in forests, gardens, settlements, rivers, and other locations that are thought to have the potential for tin ore to be mined (Pirwanda \& Pirngadie, 2015). Mining activities carried out by the local people tend to be exploitative because they not only use simple tools but also use machines. In addition, the local governments give permits to allow individuals to conduct mining freely through several regulations (Purnaweni et al., 2019). The increased mining activities have caused environmental damage around the mine area and the surrounding areas.

Upon recognizing the increasingly severe environmental damage, the government needs to make more environmentallyfriendly policies. The government must not only focus on increasing its economic growth. It must also guarantee the quality of the environment in the future. Bangka Belitung Island, often known for being Indonesia's largest tin production region, needs to end its economic dependence on tin. According to the National Development Planning Agency, promoting economic growth while being environmentally-friendly is a policy referred to as green growth (Global Green Growth Institute, 2015). Furthermore, one of the green growth policies that can be optimized is tourism potential in Bangka Belitung. In fact, the tourism sector has been designated as the leading sector by the post-mining tin government (Kurniawan et al., 2019; Prasetya \& Firmansyah, 2019; Rif'ah, 2016). 
Bangka Belitung has more economic potential besides tin production, namely tourism (Kurniawan et al., 2019). In recent years the Government is also making a policy to develop SEZs that will be built in Bangka Belitung (Purnaweni et al, 2019). There are two Special Economic Zones (SEZs) namely the Sungailiat SEZ in Bangka Regency and Tanjung Gunung in Central Bangka Regency. Both SEZs have the potential to be managed by the Indonesia Tourism Development Corporation (ITDC). The existence of these two SEZs is expected to be able to increase the local revenue and have a multiplier effect for the community (Bayu, 2018).

The intensive competition in the tourism industry recently highlights the development of two SEZs in Bangka Belitung that needs there to be synergy between stakeholders (Wardhani \& Valeriani, 2016). However its process, this SEZs policy has not been implemented as smoothly as planned thus far. This is like what happened in the SEZs development process in Sungailiat. Here it was constrained the people were still in contact with the tin mining area (Kasmono, 2020). The two regions that will be developed as SEZs areas are remain of high importance tin in terms of their tin mining potential (Friana, 2018; Purnaweni et al., 2019)

\section{RESEARCH GAP AND PURPOSE}

SEZs policy involves many stakeholders who have various interests. This conflict of interest also impacts on the development of SEZs in the two regions. The many numbers of stakeholders who have an interest in the policy of SEZ and tin mining has hampered the development of KEK in Bangka Belitung. In this article, the researchers will study and analyze the stakeholders involved based on their roles, powers, and interests. The article's purpose is to categorize and identify the role of stakeholders in the development of SEZs policy. SEZ policy is not only able to maximize the tourism potential, but it is also more environmentally-friendly. Besides this, not much research has previously been focused on the analysis of the SEZ policy stakeholders. This article is therefore a novel study examining SEZs and Bangka Belitung. In practical terms, stakeholder analysis can help to limit the issues that can be solved in ways that are technically applicable and politically appropriate by prioritizing the common interests and overall good (Bryson, 2004).

\section{LITERATURE REVIEW}

According to Farole \& Akinci, "Special economic zones are defined as geographical areas within an economy, where business activity is subject to different rules from those prevailing in the rest of the economy. Those rules can pertain to investment conditions, trade, customs, and taxes, etc" (Farole \& Akinci, 2011). Another definition is that a Special Economic Zone is an enclave of companies operating in a well-defined geographical region where certain economic activities are encouraged by a set of policy measures which typically do not apply to the rest of the world (Wahyuni, Astuti, \& Miaprajna, 2013; WEF, 2012). Most studies about SEZs described that many factors as the main drivers of SEZ competitiveness.

Generally, policy in several countries depends on the national context, governance style, and policy regime (Muhleisen \& Mukherjee, 2016). Specifically, SEZ policy in several countries of the world aims to attract investors, create new jobs and increase economic growth in certain regions (Aggarwal, 2012; Alkon, 2018) The experience in European countries such as the Balkan peninsula region SEZ policy is located near major cities or industrial cities (OECD, 2017). The reason for this is accessibility and infrastructure. SEZ policies have also been applied in several ASEAN countries such as Malaysia and Thailand. The lesson learned from the experiences of Malaysia and Thailand is that the implementation of SEZs in both countries is able to attract investors (Wahyuni, Astuti, \& Miaprajna, 2013). The successes of the two countries include the strategic position of the State, mature planning, and easy access to resources (Cipta, 2017; Wahyuni, Astuti, \& Miaprajna, 2013).

Especially in Indonesia, SEZs policy is one of the Masterplan programs for the Acceleration and Expansion of Indonesia's Economic Development (MP3EI). According to Cipta (2017) in the research that title "Special Economic Zones and Tourism Potential of Bangka Belitung Island Province", SEZs are defined as an area in the legal territory domiciled in Indonesia with certain territorial boundaries designated by the government as an area that carries out economic functions and obtains certain facilities and infrastructure. A lot of the focus of SEZs studies is on trade, mining, energy, post and telecommunications, service industries, tourism, transportation, maritime, and fisheries (Lingga \& Pratomo, 2013).

In recent years, many articles and studies have discussed the concept of stakeholders (Friedman \& Miles, 2002). The first article that discussed stakeholders was written by Freeman (1984). Stakeholder analysis has attracted the interests of scholars and researchers alike (De Vita, Lagoke, \& Adesola, 2016; Freeman, 1984). At the beginning of emerging research on stakeholders, the Stanford Research Institute agreed on the concept that stakeholders are groups that, without the support of other institutions, will cease to exist (Ackermann \& Eden, 2011). Meanwhile, Freeman defined stakeholders is individuals or groups who have an impact on the success of an organization's goals (Freeman, 1984).

Stakeholder analyzes are potentially more critical now than ever because of the world's increasingly interconnected nature (Bryson, 2004). Stakeholder analysis has an important role in the concept of public management, especially in the study of strategic management in political science and policy, planning, and corporate social performance (Ackermann \& Eden, 2011; Bryson, 2004; Freeman, 1984). First of all the stakeholder study is focused on the private sector (Ntim, 2017), and furthermore developing on the public or non-profit sector (West \& Bowman, 2004). An example of an 
empirical study on stakeholder analysis was that conducted by Dutta \& Das (2020) looking at individual or group opinions regarding rooftop solar PV systems. Stakeholder analysis, it can help to refine the evaluation process (Dutta \& Das, 2020). Additionally, stakeholder analysis has been used in land use management studies to identify problems, to determine the heterogeneity of any involved interests, to discern the interaction of stakeholders in decision making, to examine the need to review the policy objectives, and to determine the extent of the presence of cultural adjustment (Wang \& Anies, 2019). In this case, stakeholder analysis will help to resolve the problems encountered by the SEZ policy in Bangka Belitung.

There have been previous studies discussing the SEZs in Bangka Belitung. For instance, Cipta (2017) Cipta (2017) explains that the tourism potential of Bangka Belitung can be optimized through the SEZ policy while also reducing the dependence on the tin economy. Prasetya \& Firmansyah (2019) said that area is related to potential tourism. Meanwhile, according to Berthi et al., (2018) there is an emphasis on a clear pattern of cooperation between the central and local governments in the development of SEZs. Moreover, implementation of the Tanjung Kelayang (Bangka Belitung) SEZs, another area discussed in this article, involved land acquisition constraints and an unclear investment vision (Rizalsan \& Juwono, 2020). Based on several previous studies, stakeholder analysis has become appropriate to use to discuss in the development of SEZ policy in Bangka Belitung.

\section{METHODOLOGY}

This article uses a descriptive qualitative approach. This is a method used for deeply understanding the meaning of individuals or groups of people who regard something either as a social problem or as a human phenomenon. Another opinion states that descriptive qualitative research is research that aims to describe a particular social phenomenon (Creswell \& Clark, 2010). In addition, the researches have also used the approach of Participatory Action Research (PAR). This is a choice that should be regarded and recognized in qualitative research methodology (MacDonald, 2012). The locus of research was conducted in Bangka Belitung Province. The province was chosen because of Bangka Belitung has the potential of tin mining and tourism. There is also the local interest in the development of multiple Special Economic Zones.

This research focuses on how the roles of each stakeholder are based on their strengths and interests. The discussion that follows is organized into three sections. The first focuses on the policy of the SEZs in Bangka Belitung, especially the SEZs of Tanjung Gunung and Sungailiat. The second focus is the stakeholder analysis and the importance of stakeholder analysis to solve any problems that arise. The third is regarding the stakeholder analysis conducted. It was found that the existence of local leaders strengthens the lack of community participation caused by the development of SEZs.

The researchers obtained the necessary data through in-depth interviews, observation, and a literature study on the focus of research. About 30 informants were consisting of 10 elements of government/university, 2 elements of investors, and 18 individuals from of society. The selection of the informants was done using purposive techniques and the questions were semi-structured in nature. In addition, the researchers also conducted focus group discussions with the related agencies and institutions within the Bangka Belitung Province Government, Bangka Regency, and Central Bangka Regency. The researchers determined who the ideal informants would be beforehand as they are considered to be important and thus key informants. Furthermore, the researcher used the snowball technique based on the information obtained from the key informants (Sugiyono, 2016). Several informants were from the Regional Development Planning Agency (Bappeda) of Bangka Belitung Province. Bappeda Bangka Regency, Bappeda Central Bangka Regency. The academics were Belitung University and several staff in the Central Bangka and Bangka Regency Offices.

\section{RESULTS AND DISCUSSION}

As we know, Indonesia has natural and cultural diversity which can be used to develop the tourism sector. This might contributes to increasing the national income (Baskara, Hendarto, \& Susilowati, 2017). Therefore the government has formulated a top-down policy regarding Special Economic Zones. Special Economic Zones were formulated by the National SEZ Council to increase the economic growth in the region to help the government obtain more foreign exchange. Another argument is that the SEZ development policy in Bangka Belitung is an effort made by the government to stop the regional dependence on tin mining. This is because tin mining has contributed significantly in terms of environmental damage. The SEZ policy in the two regions, namely Sungailiat and Tanjung Gunung, is intended to be the driving force behind the local economy like the SEZ previously built-in Tanjung Klayar.

\section{SEZs Policy in Bangka Belitung}

The existence of SEZs in a country aims to increase investment, increase employment, foreign exchange, improves the function of utiliziation of both local and general resources (Alkon, 2018; Yang et al., 2019). ). In the tourism sector, SEZs are expected to be able to optimize the resources and potential of tourism for the prosperity of the community. Through tourism, new sources of employment will emerge that can absorb more workers. In addition, the tourism sector will reduce the economic dependence on oil, gas, and the mining sector.

According to the Government perspective, the policy development of special economic zones in Bangka Belitung aims to open up a great opportunity and economic benefits (Marta et al., 2019). After successfully developing the SEZ in the Tanjung Kelayang area in 2019, the Government and National SEZ Council have reviewed two areas to be developed by 
the SEZs in Tanjung Gunung and Sungailiat. Tanjung Gunung SEZ is about seven kilometers from Pati Amir Airport and it has an area of around 385 hectares. Meanwhile, Sungailiat SEZ is about 40 kilometers from Pati Amir Airport with an area of 600 hectares. Both of these SEZs have a different purpose. The Tanjung Gunung SEZ will be reserved for tourism and Meeting, Incentives, Conferences, and Exhibition (MICE). Meanwhile, the Sungailiat SEZ will be for sports tourism. The existence of two SEZs is hoped to make the area a world-class destination in the future.

The SEZs policy is a policy of the central government, although the process of developing the operational assistance system is grounded in the regional authority. The SEZ policy was approved by the government in Government Regulation (PP) No.6 / 2016 (Figure 1). Only two SEZs are being developed because the analysis of the tourism potential of Bangka Belitung has not been optimized. This SEZ seeks to maintain the existing environmental ecosystem and it does not damage the environment in the same way as tin mining.

\section{SEZs Policy in Bangka Belitung}

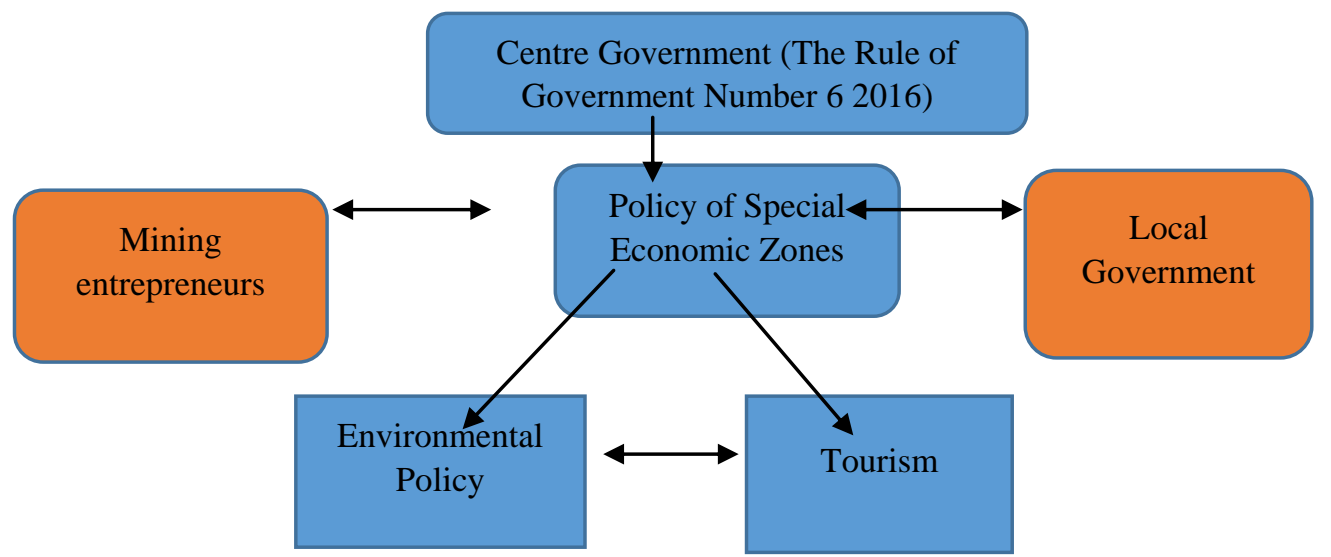

Figure 1: The Framework of Bangka Belitung SEZ

Source: Author configuration

The preparation and development of the SEZs have been ongoing for two years, starting from their socialization up until development. In fact, the central government has only provided facilitation (SEZ policy) while the regional government has executed it. Up until early 2020, the development of the SEZs in the two regions has still encountered several obstacles. The most crucial is the conflict of interest related to the land status. The two SEZs cover a number of hectares of land that intersect with the Mining Business License (IUP) owned by PT Timah. In addition, there are still overlapping regulations in reference to the mining and tourism permit areas that have become obstacles to developing the SEZ policy in Bangka Belitung.

In fact, the SEZ policy is a policy issued by the government that describes the environmental problems in Bangka Belitung as due to the impact of tin mining and its exploitation. Policy science is based on problems. The perspective needed to solve the problems that arise varies from setting to setting. Conceptually, the study of policy is deliberative and democratic (deLeon, 1990). Another argument is that we must remember that there are many stakeholders involved in tin mining, including the common community. This argument is often an obstacle for the implementer. The provincial government through the governor has stated its high level of commitment to the development of SEZs in Bangka Belitung. The SEZ development is expected to divert the economic concentration from mining to the tourism sector. Especially in the areas that will be turned into Special Economic Zones, there are still many obstacles encountered such as inadequate infrastructure, a lack of socialization of the community, and many actors, especially mining business actors, who still have interests contrary to the two SEZ areas.

\section{Stakeholder Analysis for Environmental Policy-SEZs}

Within the scope of the policy, stakeholder analysis will help in the process of achieving the goals effectively in the public interest. When we make a policy or make a decision to solve a social problem, it is almost certain to involve a number of people, groups, and organizations. This has happened in the process of the SEZ development in Bangka Belitung. Lots of actors and stakeholders have certain interests that influence their response to the SEZ policy. In this case, the SEZ development policy is part of the government's efforts to lessen the risk of environmental degradation due to the influence of tin mining. This is regardless of whether or not tin mining has been recognized as having a negative impact on the environment in Bangka Belitung (Purnaweni, et al, 2019). Through the SEZ policy, the government intends to divert the mining economic resources into a tourism-based economy. This has an indirect impact on the environmental sustainability in the future. Environmental policy in a region is needed to guarantee the availability of the environment in the future, although it is not easy and can encounter many obstacles.

What is an environmental policy? Environmental policies are something done by a public organization or government to maintain the continuity of the human environment and that of other living things (Roziqin, 2018). In addition, 
environmental policies are formulated and implemented in light of the national, economic, and cultural context of a country and the specific definition of sustainable development (Tuokuu et al, 2019). This is supported by the Sustainable Development Goals (SDGs) that have been agreed on in various countries. Intensive environmental management is important to ensure the balanced use of natural resources (Ahmed, 2019), of which one such instrument is policy. Furthermore, the environmental policies vary depending on the political will and regional characteristics. The provincial government of Bangka Belitung has opted to support the SEZ policy. Besides being considered environmentallyfriendly, the SEZ policy will contribute positively to the regional income. Thus the SEZ policy in Bangka Belitung is very interesting to discuss from the perspective of stakeholder analysis.

As an alternative environmental policy to that of tin mining, the environmental governance in the SEZ policy is a challenge for the government, private sector, local communities, and other agencies that have an interest (Darimani, Akabzaa, \& Attuquayefio, 2013; Tuokuu et al, 2019). Furthermore, why is the stakeholder approach used in this research? The tradition of stakeholders being involved emphasizes the meaning of networked relationships, highlighting the connections and social transactions between various groups (West \& Bowman, 2004). Policies are multidisciplinary and require many actors and stakeholders. This has an impact on the importance of this study. Stakeholder analysis will help to examine who the stakeholders are that are involved in this policy. This can facilitate the achievement of the policy objectives. Stakeholder analysis will help to examine who the stakeholders are in the policy, thus facilitating the policy objectives.

Considering power and interest, researchers have tried to identify holistically who the stakeholders are that are involved in SEZ policy. Identifying the stakeholders was an early task in the analysis (MacArthur, 1997). The existence of policy identification is a tool used to discuss the relationship patterns between each stakeholder based on the role that they have (Yustisi, 2018). As part of identifying the stakeholders and conducting the appropriate stakeholder analysis, the researchers in this study used the "Power-Interest Grid" (Figure 2). This method is used to determine the stakeholders who hold the key role in order to formulate a strategy based on their power and interest (Freeman, 1984; Ackermann \& Eden, 2011)

Based on interviews and secondary data was obtained by the researcher. There are 6 stakeholders identified.

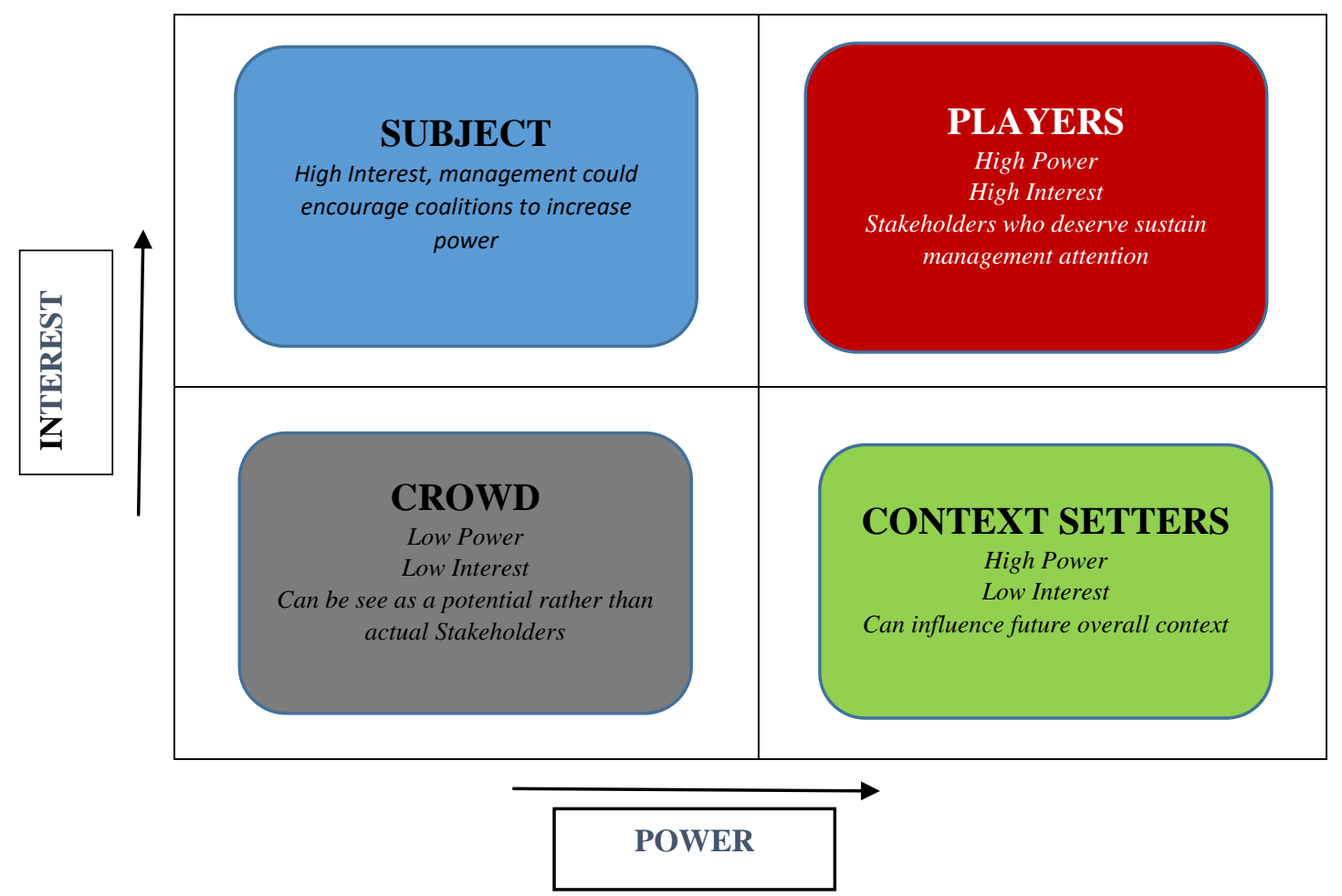

Figure 2: Framework of Stakeholders Identification

Source: Adapted from (Ackermann \& Eden, 2011)

\section{PLAYERS}

National Council of Special Economic Zones holds high power and interest in the development of SEZ. In pursuant to the mission, the duty of the Council are to provide facility in administration, recommendation, regulation, coordination, and institutional capacity development. The central government is included in the players category because it has a high level of interest in the development of SEZ policy in Bangka Belitung. According to the National SEZs Council, the SEZ Policy in Indonesia incorporates 6 sector zones, namely export management, logistics, technology development, 
industry, tourism, energy, and other economic activities. The SEZs in Bangka Belitung are focused on the tourism sector. Specifically, the tourism sector over the years has shown a positive trend and continues to grow. According to the Central Statistics Agency, the value of economic transactions in 2017 reached Rp 634 trillion, an increase of 8.4 percent compared to the previous year of Rp 584.89 trillion. For 2018, the tourism sector will be able to contribute to the country's foreign exchange of US $\$ 14.1$ billion.

The central government is presently experiencing confusion between the development of the SEZs and the tin mines. The main factor hampering the development of SEZs in Tanjug Gunung and Sungailiat is tin mining. Up until now, the government's decision has not provided legal certainty for SEZ development. This is because the government is still giving permission for the mining authority of PT. Timah to resume work in the two regions. PT. Timah itself is a government-owned company, so it certainly has an impact on the foreign exchange earnings from the mine. This fact will certainly be very detrimental to the SEZ development policies. The provincial government continues to push to optimize the tourism sector.

Under Jokowi's second period, the government is serious about optimizing the tourism sector. The government is massively encouraging the regions to develop their tourism potential. This is evidenced by the government's support of the development of SEZs in several regions, in addition to revitalizing the existing tourist destinations. The development of the SEZ policy in Bangka Belitung has appointed the National SEZs Council under the supervision of the Coordinating Ministry for Economic Affairs as a task force that coordinates the SEZ development plans in the various regions of Indonesia. The National SEZ Council coordinates with other ministries when preparing the SEZs. Specifically, the SEZ policy in Bangka Belitung involves several Ministries including the Coordinating Ministry for Economic Affairs, the Ministry of Tourism, the Ministry of Energy and Mineral Resources, and the Ministry of Agrarian Affairs and Spatial Planning to plan the spatial details. The central government only provides the facilities and some of the supporting infrastructure while the local government will operate it more directly.

\section{SUBJECT}

Regardless they do not have authority to make decision by SEZs, the Local Government including Province Regency is a part of subject because they have high interest. Moreover, either Bangka Belitung Province and Region of Central Bangka and Bangka Region are solely giving support to SEZs policy. The provincial government through the governor (Erzaldi Rosman) has been actively encouraging the development of SEZs in Bangka Belitung. The provincial government is committed to managing the tourism potential that it has in both regions (Lubis, 2020). The trademark owned by Bangka Belitung Province is as a tin producer, although in recent years the government has tried to change this by maximizing the tourism potential. After successfully developing tourism in Belitung through the film trilogy "Laskar Pelangi," Bangka Belitung began to be famous as an area that has exotic natural beauty. Based on this opportunity, the provincial government wants to build SEZs in two areas at once, namely in Tanjung Gunung and Sungailiat. Head of Development Planning Agency (Bappeda) as a sub division of Local Government of Central Bangka Region also support SEZs planning by creating a forum among stakeholders to robust sustainable development plan especially in the coast area.

The strong commitment from the provincial government places as a player in the framework of the stakeholders. In addition, the provincial government also has official legitimacy that can be used to influence policy. However, the provincial government is not a key player because the two SEZ areas are located in Central Bangka Regency and Bangka Regency. Both of them still awaiting the final decision from the central government to get legality. The central government has a broader authority over the SEZs strategic plan, which in its development is something that needs to be questioned.

Some of the agencies under the provincial government involved in the SEZ policy include the Regional Development Planning Agency, the Tourism Office, the Industrial Service, and the Environmental Service. They coordinate and support one another in their support of the provincial government's commitment under the direction of the Governor. One of the agencies above these that has a higher level of interest than the other agencies is the Office of Tourism. Furthermore, the provincial government will also make regional regulations related to governing zoning in the future.

\section{CONTEXT SETTERS}

Two SEZ areas, namely Tanjung Gunung and Sungailiat, are in the Bangka archipelago. As we know, most of the Bangka region is the largest tin-producing area in Bangka Belitung Province. Therefore the biggest factor that hinders the development of SEZs is the presence of tin mines (Pratama, 2020). There are many companies both national and privately state-owned that are conducting tin mining. One company that is still actively mining is PT. Timah still has Mining Authorities in the two regions of note and will do until 2025. The big interests of the tin entrepreneurs involved will certainly have an impact on the progress of the SEZ development in the region.

The legal aspect that is still owned by the tin companies has narrowed the space available for the provincial and regency governments to free up the mining land in order for it to become a tourism area. Besides that, there is also a lot of unconventional mining land owned by the people. This form of activity has increased significantly after the reform era (Purnaweni, et al, 2019). This means that the tin mining industry and entrepreneurs have no interest in the SEZ policy. 
Mining activities are a big commodity because the profits are quite large, hence the companies and other mining industry players will not make it easy to just let go of the mine that they have.

The authority to validate SEZ's policy lies on the central government. Nevertheless, the difference interest among the stakeholders at central level and sectoral ego are that pronounced while SEZ has not been validated. It is known that the Ministry of Mining still issuing permits in the SEZ area (CNN, 2018). The inter-stakeholders cooperation are essential to achieve the success of the SEZ policy as it happened in the SEZ development in Tanjung Lesung, Banten (Kismartini \& Bambang, 2020)

\section{CROWD}

Many of the people living in the Bangka Regency and Central Bangka Regency disagree with the SEZ policy. The community feels less involved and many do not know about the SEZ policy. The majority of them refuse it because it would reduce the yield from the tin mines. It should be noted that in Bangka Belitung Province especially around the SEZ area, there are a lot of community-owned mines. The official term is Unconventional Mining (TI). This condition is very different from what has happened in the Belitung Regency where the community at large supports the development of tourism. The Belitung Regency community fully supports the government's efforts to improve the tourism sector.

Without the support and participation of the community (local) regarding a policy, it is possible to obstruct the success of the policy. As determined through previous policy studies, the community not only is the recipient object, but it is also the implementing subject. As a result, community participation is needed to achieve the policy objectives. In this case, the community has a low interest in the SEZ policy as well as not having the power to take part in the SEZ development process. The community's position is very weak and it is positioned as a crowd in stakeholder analysis.

According to Clarkson (1995) in the process of stakeholder identified, there are 3 types, namely key stakeholders, primary stakeholder, and secondary stakeholder:

1. Key stakeholders are the groups or individuals whose participation greatly influences the performance of the organization. If the key stakeholders withdraw their support from the organization, then the organization cannot survive sustainably. Based on the previous explanation, the provincial and central government actors are the key stakeholders in terms of SEZ policy. These two actors can influence how and whether the SEZ policy continues or not because they have the power and interests that influence the policy.

2. Primary stakeholders have a high degree of complexity. This means that this group has a strong relationship with the other interest groups which have differences between the rights, expectations, or roles or who receive positive or negative impacts associated with them. In the development of the SEZ policy in the Bangka Regency and Central Bangka Regency, there is a certain level of intensity within the interest groups of investors and tin mining businesses.

3. Secondary stakeholders are the groups that influence and are influenced by the organization, but they are not involved in the organizational interactions and policy-making. In reference to the SEZ policy, the secondary stakeholders are the community and tin mining business actors. These two stakeholders have never been directly involved in the policy-making process but they can influence the success of the SEZ policy.

Using "Power-Interest Grid", the researchers have formulated the presence of several stakeholders and placed them in the table as follows:

Table 1: Status and Stakeholders

\begin{tabular}{ll}
\hline Status & Stakeholders \\
\hline Subject & Provincial Government \\
\hline Players & Central Government \\
\hline Context Setters & Tin entrepreneurs, regency government \\
\hline Crowd & Local Communities \\
\hline
\end{tabular}

Source: Author analysis

\section{Commitment of the Central Government and a Lack of Participation}

A great deal of the current research and literature addressing the stakeholders is derived from the broader interest of the development aid organizations participating in the development process (MacArthur, 1997). Specifically, regarding the SEZ policies in Bangka Belitung, the researchers saw that there was a problem in terms of the participation of several stakeholders especially in the context of the grid setters and crowds (see Figure 2) who were predominantly from the mining businesses, local government and the community. Their lack of participation has had an impact on achieving the policy objectives and for more than 2 years, the SEZ policies in the two regions have not been implemented.

Since the publishing of Law number 4 of 2009 concerning mineral and coal mining, the local government has the authority to manage the mine while still coordinating with the central government. As a result, the local government gave anyone the freedom to mine in Bangka Belitung. The Local Government responded by publishing local regulations 
(see Darwance et al., 2017) that specifically manage at the local level. This exercising of authority has had an impact on increasing tin mining in Bangka Belitung (Purnaweni et al., 2019). Many local stakeholders have interests in the mining industry. Moreover, there are considerable economic opportunities. In addition, the community has many tin mines in the two regions. As a result, the transition effort from the tin mining economy to the tourism economy faces a major obstacle.

There are some researches suggests that the failure or success of a zone is linked to its policy and incentive framework, where it is located, and how it is developed and managed (World Bank, 2008). An SEZ policy is top-down, including when determining the SEZ and places therein and how they are managed. This has an impact on the lack of community participation. The policy needed to optimize the tourism sector should not be a geosite exclusively and rely on natural beauty alone. It should also invite community-based tourism. Not only should it be able to preserve the environment but it should also empower the community in order to have an impact on the economic changes ongoing due to the transition away from mining. The community considers tin mining to be more economically advantageous than turning to SEZ policies. There are those in the community who are against mining because they are affected by the mining activities. For example, there is turbid water output, or no benefits at all are felt as a result of the tin mining. Mining itself in the Bangka land area has started to run out, so the IT miners and PT. Tin has begun to shift their explorations into the sea area by $0-4$ miles. As a result, fishermen have complained about the mining at sea because they have difficulty finding fish.

Tin mining has become a major factor in inhibiting the SEZ policy. A few of the researchers encountered the residents' unconventional mines. The two areas projected to be special economic zones are still hampered by land acquisition which has become controlled by KP (Mining Authority) from PT. Timah until 2025. This means that PT. Tin has the right to mine the entire KP area. Based on Law number 4 of 2009 concerning Mineral and Coal Mining, this KP matter has caused confusion for the local leaders and mining industry alike because the KP in the Law (4/2009) has never been discussed in detail.

The central government has the power to influence policy. Based on several informants that the researchers met, actually from the provincial government level has a strong political will to build SEZs. The provincial government through the Governor of Bangka Belitung Province has agreed to transform its economic focus from tin mining to tourism. The two regions that will be developed into SEZs have been legalized through Bangka Belitung Province regional regulation number. 3/2020. The regulation determines the Zoning Plan for Coastal Areas and Small Islands (RZWP3K) for the Province of Bangka Belitung (Lubis, 2020). However, this was not supported by the central government. The central government has not yet passed a regulation to formalize the Tanjung Gunung and Sungailiat SEZs (Kasmono, 2020)

Furthermore, all stakeholders need to have the same goal, namely the achievement of any enacted SEZ policies. Without the clear vision and goals of each stakeholder, the SEZ policy in Bangka Belitung can't be realized. The ego conflicts between stakeholders and associated conflict of interests need to be set aside by all stakeholders. Although it is difficult, ideally stakeholders need to realize that the SEZ policy will benefit the economic development of the community and promote environmental sustainability in the future. If the key stakeholders and players dare to make policies that prohibit tin in the two SEZ areas, then it is very likely that the SEZ policy will be successful.

\section{CONCLUSION}

The findings of this research have implications for both theoretical and applied purposes. For the theoretical purpose, this research shows that stakeholder analysis is an important part of mapping out the role of the involved stakeholders based on their power and interest. This serves to identify the stakeholders who have a key role in implementing the associated policy. Meanwhile, for the applied purpose, this research can identify the problems associated with the constraints of the SEZ policy development in Bangka Belitung. This research provides ideas for solving the problems of stakeholders who are considered not to contribute to the SEZ policy development. The SEZ policy in Bangka Belitung can thus be realized properly and achieve the goals set previously.

The analysis states that the main factor that inhibits the SEZ policy in Bangka Belitung is tin mining. In addition, the findings in this research show that the central government (National Council of Special Economic Zones) is a players with a high level of power and interest in policy of SEZ. The central government has not made a clear commitment to the development of SEZ policy in Bangka Belitung. Furthermore, the SEZ policy has many stakeholders involved with diverse interests. Bringing up the dynamics generated is very complex.

The success of a policy is not only determined by the government (Local and Central) but also the community in terms of how it can target and be accepted by the community. In the context of the SEZ policy, the community should be more involved in the process of developing the tourism industry in Bangka Belitung. Some of the tourism industry areas that have emerged in Indonesia are inseparable from the large role of the local communities. Community-based tourism can be an alternative for stakeholders to use to develop SEZs, although this is still constrained. The community will be enthusiastic if they are involved in the development of the new policy. The SEZ policy in Bangka Belitung is an attempt by the government to change the economic structure of the region which is dependent on the change in the mining output by additionally optimizing the tourism sector. Starting from 2018 and progressing up until now, the SEZ policies have encountered many obstacles such as the presence of tin mines, a lack of commitment by the Regency government, and a 
lack of support from the community itself. Therefore future research must analyze the role of the local government in supporting the government policies above, especially the policies related to the economy and the environment.

\section{LIMITATION AND STUDY FORWARD}

This article focuses on the development of SEZ policy in Bangka Belitung. The stakeholder analysis can have many variations depending on the problem and the actors involved. Based on the results of this research, the next research that can be undertaken is looking into how local governments have an important role in the effort to build a climate of sustainable development. This can be done by making policies that are environmentally-friendly while still having a positive impact on the economy of the local community. Moreover, there should be the existence of a law on mining that restores the central authority to the tin mining governance

\section{ACKNOWLEDGEMENT}

We would like to thanks for Directorate of research and community service, Deputy of Strengthening Research and Development Ministry of Research and Technology/National Research and Innovation Agency which has funded this research with a contract number 257-38/UN7.6.1/PP/2020. Also thanks to Research Institutions and community services of Universitas Diponegoro (UNDIP) that has supported this publication and enhance the collaboration between UNDIP and Universitas Muhammadiyah Malang (UMM) to join this study.

\section{REFERENCES}

1. Ackermann, F., \& Eden, C. (2011). Strategic Management of Stakeholders: Theory and Practice. Long Range Planning, 44(3), 179-196. https://doi.org/10.1016/j.lrp.2010.08.001

2. Aggarwal, A. (2012). Social and economic impact of SEZs in India. Ofxford University Press. https://doi.org/10.1093/acprof:oso/9780198077275.001.0001

3. Ahmed, B. (2019). Environmental governance and sustainable development in Bangladesh: millennium development goals and sustainable development goals. Asia Pacific Journal of Public Administration, 41(4), 237-245. https://doi.org/10.1080/23276665.2019.1698930

4. Alkon, M. (2018). Do special economic zones induce developmental spillovers? Evidence from India's states. World Development, 107, 396-409. https://doi.org/10.1016/j.worlddev.2018.02.028

5. Bank, W. (2008). Special Economic Zones: Learned, Lessons, Learned, and Implications for Zone Development. Washington, DC.

6. Baskara, K. A., Hendarto, R. M., \& Susilowati, I. (2017). Economic's valuation of marine protected area ( MPA ) of Karimunjawa, Jepara-Indonesia. AACL Bloflux, 10(6), 1554-1568.

7. Bayu, D. J. (2018). Dua Daerah di Bangka Belitung Bakal Jadi Kawasan Ekonomi Khusus. Retrieved January 12, 2020, from https://katadata.co.id/berita/2018/11/05/dua-daerah-di-bangka-belitung-bakal-jadi-kawasanekonomi-khusus

8. Berthi, R., Sulistyaningsih, T., \& Hadi, K. (2018). Government Cooperation (Study of the Cooperation between the Central and Regional Governments in the Development of Tourism Priority Destinations in Tanjung Kelayang, Bangka Belitung). Journal of Local Government Issues, 1(2), 202. https://doi.org/10.22219/logos.vol1.no2.202-225

9. Bryson, J. M. (2004). What to do when stakeholders matter: Stakeholder Identificatixon and analysis techniques. Public Management Review, 6(1), 21-53. https://doi.org/10.1080/14719030410001675722

10. Cipta, H. (2017). Kawasan Ekonomi Khusus dan Potensi Pariwisata Provinsi Kepulauan Bangka Belitung. Taushiyah, 12(1), 1-18.

11. Clarkson, M. E. (1995). a Stakeholder Framework for Analyzing and Evaluating Corporate Social Performance. Academy of Management Review, 20(1), 92-117. https://doi.org/10.5465/amr.1995.9503271994

12. Creswell, J., \& Clark, V. P. (2010). The foundations of mixed methods research. Designing and Conducting Mixed Methods Research.

13. Darimani, A., Akabzaa, T. M., \& Attuquayefio, D. K. (2013). Effective environmental governance and outcomes for gold mining in Obuasi and Birim North Districts of Ghana. Mineral Economics. https://doi.org/10.1007/s13563-013-0036-2

14. Darwance, Nugroho, S., \& Yokotami. (2017). Strategi Pengelolaan Sumber Daya Alam Dalam Pengaturan Pertimahan Di Provinsi Kepulauan Bangka Belitung: Dari Zaman Voc Hingga. 2017, 536-549. Jember: Prosiding Seminar Nasional dan Call For Paper Ekonomi dan Bisnis (SNAPER-EBIS 2017).

15. De Vita, G., Lagoke, O., \& Adesola, S. (2016). Nigerian oil and gas industry local content development: A stakeholder analysis. Public Policy and Administration, 31(1), 51-79. https://doi.org/10.1177/0952076715581635

16. deLeon, P. (1990). Participatory Policy Analysis: Prescriptions and Precautions. Asian Journal of Public Administration, 12(1), 29-54. https://doi.org/10.1080/02598272.1990.10800227

17. Dutta, A., \& Das, S. (2020). Adoption of grid-connected solar rooftop systems in the state of Jammu and Kashmir: A stakeholder analysis. Energy Policy, 140(May 2019), 111382. https://doi.org/10.1016/j.enpol.2020.111382

18. Erman, E. (2008). Deregulasi tata niaga timah dan pembuatan negara bayangan lokal; Studi kasus Bangka. In 
G. V. K. Henk Schulte Nordholt \& (Ed.), Politik lokal di Indonesia. Jakarta: Yayasan Obor Indonesia.

19. Erman, E. (2010). Aktor, akses dan politik lingkungan di pertambangan timah Bangka. Masyarakat Indonesia, 36(2), 71-101. https://doi.org/10.14203/jmi.v36i2.640

20. Farole, T., \& Akinci, G. (2011). The Special Economic Zones: Progress, Emerging Challenges, and Future Directions. In The World Bank. https://doi.org/10.1596/978-0-8213-8763-4

21. Forum, W. E. (WEF). (2012). The global competitiveness report 2011-2012. In World Economic Forum (Vol. 5). https://doi.org/92-95044-35-5

22. Freeman, E. (1984). Strategic Management: A Stakeholder Approach. Boston: Pitman.

23. Friana, H. (2018). Penetapan Kawasan Ekonomi Khusus di Babel Terkendala Tambang. Retrieved January 10, 2020, from https://tirto.id/penetapan-kawasan-ekonomi-khusus-di-babel-terkendala-tambang-c9dc

24. Friedman, A. L., \& Miles, S. (2002). Developing stakeholder theory. Journal of Management Studies, 39(1), 121. https://doi.org/10.1111/1467-6486.00280

25. Global Green Growth Institute. (2015). Mewujudkan Pertumbuhan Ekonomi Hijau untuk Indonesia yang Sejahtera. Jakarta: Badan Perencanaan dan Pembangunan Nasional.

26. Ibrahim. (2016). Bangka Tin , and the Collapse of the State. GSTF Journal of Law and Social Sciences (JLSS). https://doi.org/10.5176/2251-2853

27. Indonesia, C. (2018). Rencana Dua KEK Pariwisata di Babel Terganjal Pertambangan. Retrieved April 4, 2020 , from https://www.cnnindonesia.com/ekonomi/20181105150443-92-344113/rencana-dua-kek-pariwisata-dibabel-terganjal-pertambangan

28. Kasmono. (2020). Bupati Bangka berharap Ketua DPD RI mampu wujudkan KEK Pariwisata. Retrieved January 16, 2020, from https://www.antaranews.com/berita/1240559/bupati-bangka-berharap-ketua-dpd-rimampu-wujudkan-kek-pariwisata

29. Kismartini,K., Pujiyono, Bambang. (2020). Collaborative Management Model Tanjung Lesung Tourism in Pandeglang District, Banten Province, Indonesia. https://doi.org/10.30892/gtg.302spl12-516

30. Kurniawan, N. I., Azizah, N., Wardhani, I. S., Djindan, M., Arti, W. C., Putri, P. S., \& Cahyati, D. D. (2019). Pariwisata Sebagai Strategi Transisi Ekonomi Pasca Timah di Pulau Belitung.

31. Lingga, D., \& Pratomo, W. (2013). Persepsi Masyarakat Terhadap Pengembangan Kawasan Ekonomi Khusus Sei Mangkei Sebagai Klaster Industri. Jurnal Ekonomi Dan Keuangan, 1(2), 13-20.

32. Lubis, M. S. W. (2020). Realisasi Dua Kawasan Ekonomi Khusus di Bangka Didukung Perda. $\begin{array}{lllll}\text { Sumatra.Bisnis.Com. } & \text { Retrieved } & \text { September } & \text { 9, } & \text { 2020, }\end{array}$ https://sumatra.bisnis.com/read/20200716/534/1267263/realisasi-dua-kawasan-ekonomi-khusus-di-bangkadidukung-perda

33. MacArthur, J. (1997). Stakeholder analysis in project planning: Origins, applications and refinements of the method. Project Appraisal, 12(4), 251-265. https://doi.org/10.1080/02688867.1997.9727068

34. MacDonald, C. (2012). Understanding PAR A Qualitative Research Methodology option. Canadian Journal of Action Research, 13(2), 34-50.

35. Marta, Auradian; Agustino, Leo; Suwaryo, Utang; Sulaeman, A. (2019). Oil Palm Plantation Development in Riau Province: An Overview of The Political Economy. Jurnal Ilmu Sosial, 17(2), 128-144. https://doi.org/10.14710/jis.17.2.2018.128

36. Muhleisen, J., \& Mukherjee, I. (2016). Policy analysis: a rich array of country and comparative insights. Asia Pacific Journal of Public Administration, 38(3), 204-210. https://doi.org/10.1080/23276665.2016.1217663

37. Ntim, C. G. (2017). Defining Corporate Governance: Shareholder Versus Stakeholder Models. In Global Encyclopedia of Public Administration, Public Policy, and Governance. https://doi.org/10.1007/978-3-31931816-5_3132-1

38. OECD. (2017). Tracking Special Economic Zones in The Western Balkans.

39. Pirwanda, F., \& Pirngadie, B. H. (2015). Dampak Kegiatan Tambang Timah Inkonvensional Terhadap Perubahan Guna Lahan di Kabupaten Belitung. Jurnal Planologi Unpas.

40. Prasetya, Z. W., \& Firmansyah. (2019). Identifikasi Potensi Wisata Pantai Rampak Guna Mendukung Rencana Pengembangan Calon Kawasan Ekonomi Khusus di Kecamatan Sungailiat [Universitas Pasundan]. http://repository.unpas.ac.id/43212/

41. Pratama, R. (2020). KEK Tanjung Gunung Terhambat gara-gara IUP PT Timah, Kini Dokumen Selesai Tinggal Tunggu Presiden. Retrieved from https://bangka.tribunnews.com/2020/01/03/kek-tanjung-gunung-terhambatgara-gara-iup-pt-timah-kini-dokumen-selesai-tinggal-tunggu-presiden

42. Purnaweni, H., Kismartini, Prabawani, B., \& Roziqin, A. (2019). Bangka Belitung Islands: Great Potencies of Massive Environmental Impacts. E3S Web of Conferences, 125(23), 8-12. https://doi.org/10.1051/e3sconf/201912509008

43. Purnaweni, H., Kismartini, Prabwani, B., \& Roziqin, A. (2019). Politics and Business: The Policy on Tin Mining in Bangka. International Journal of Business and Economic Affairs, 4(3), 133-139. https://doi.org/10.24088/IJBEA-2019-43004

44. Rif'ah, N. (2016). Hotel Resor di Pantai Tanjung Berikat, Bangka. Retrieved January 13, 2020, from http://eprints.undip.ac.id/50702/2/NENY_RIF\%27_AH_21020112130125_BAB_I.pdf

45. Rizalsan, A., \& Juwono, V. (2020). Ekonomi Khusus Tanjung Kelayang Policy Implementation Of Tanjung 
Kelayang Special Economic Zone. Jurnal Borneo Administrator, 16(2), 159-178. https://doi.org/10.2458/jba.v16i2.676

46. Roziqin, A. (2018). Environmental Policy of Mangroves Management in Rembang Regency. E3S Web of Conferences. https://doi.org/10.1051/e3sconf/20183109002

47. Sugiyono. (2016). Memahami Penelitian Kualitatif. Bandung: Alfabeta.

48. Sujitno, S. (2007). Dampak Kehadiran Timah Indonesia Sepanjang Sejarah. Jakarta: Cempaka Publishing.

49. Tuokuu, F. X. D., Idemudia, U., Gruber, J. S., \& Kayira, J. (2019). Linking stakeholder perspectives for environmental policy development and implementation in Ghana's gold mining sector: Insights from a Qmethodology study. Environmental Science and Policy, 97(April), 106-115. https://doi.org/10.1016/j.envsci.2019.03.015

50. Wahyuni, S., Sri Astuti, E., \& Karina Miaprajna, U. (2013). Critical Outlook at Special Economic Zone in Asia : A Comparison Between Indonesia, Malaysia, Thailand and China. 28(3), 336-346.

51. Wang, J., \& Aenis, T. (2019). Stakeholder analysis in support of sustainable land management: Experiences from southwest China. Journal of Environmental Management, 243(April), 1-11. https://doi.org/10.1016/j.jenvman.2019.05.007

52. Wardhani, R. S., \& Valeriani, D. (2016). Green Tourism Dalam Pengembangan Pariwisata Bangka Belitung. Green Tourism Dalam Pengembangan Pariwisata Bangka Belitung, 275-286.

53. West, J. P., \& Bowman, J. S. (2004). Stakeholder Analysis of Civil Service Reform in Florida: A Descriptive, Instrumental, Normative Human Resource Management Perspective. State and Local Government Review, 36(1), 20-34. https://doi.org/10.1177/0160323x0403600102

54. Yang, Z., Wang, Y., \& Liu, Z. (2019). Improving socially inclusive development in fast urbanized area: Investigate livelihoods of immigrants and non-immigrants in Nansha Special Economic Zone in China. Habitat International, 86(November 2018), 10-18. https://doi.org/10.1016/j.habitatint.2019.02.005

55. Yustisi, M. J. (2018). Analisis Stakeholders Dalam Pengelolaan Objek Wisata Gili Trawangan di Kabupaten Lombok Utara. Jurnal Tata Sejuta STIA Mataram, 4(1), 1-16. https://doi.org/10.32666/tatasejuta.v4i1.27 